\title{
SZERSZÁMACÉLOK FELÜLETI KOPÁSÁLLÓSÁGÁNAK NÖVELÉSE FELÜLETKEZELÉSSEL
}

\section{TOOL STEELS SURFACE WEAR RESISTANCE INCREASING BY SURFACE TREATMENT}

\author{
Tóth László, ${ }^{1}$ Nyikes Zoltán, ${ }^{2}$ Mhatre Umesh ${ }^{3}$ \\ 1,2 Óbudai Egyetem, Bánki Donát Gépész és Biztonságtechnikai Mérnöki Kar. Budapest, Magyarország, \\ toth.laszlo@bgk.uni-obuda.hu,nyikes.zoltan@phd.uni-obuda.hu \\ ${ }^{3}$ Surface Modification Technologies Pvt. Ltd. Mombai, India, umhatre.smtpl@gmail.com
}

\begin{abstract}
The industry is imposing increasing wear and tear requirements on tools, which can no longer be satisfied with the development of base materials (tool steels). Surface treatment technologies can provide a solution as the surface of the working tool must be suitable. It can determine a relationship between the hardness, surface roughness and the abrasion resistance of various surface treatments and the coating technologies such as PVD as a result of tool steel surface layers. These relationships form the basis for tool selection and provide a theoretical basis for the design of surface technologies.
\end{abstract}

Keywords: hardness, wear resistance, $P V D$ process, surface treatment.

\section{Összefoglalás}

Az ipar a szerszámokkal szemben egyre nagyobb kopásállósági követelményeket állít, mely az alapanyagok (szerszámacélok) fejlesztésével már nem elégíthető ki. A felületkezelési technológiák megoldást kínálhatnak, hiszen a szerszámok dolgozó felületeinek kell megfelelőnek lenniük. Megvizsgálva a keménységet, a felületi érdességet és a különböző felületkezelések és bevonatolási technológiák, mint a PVD eredményeként létrejött szerszámacél-felületi rétegek kopásállóságát, összefüggéseket lehet feltárni. Ezen összefüggések alapját képezik a szerszámkiválasztásnak, és a felületi technológiák tervezéséhez elméleti hátteret adnak.

Kulcsszavak: keménység, kopásállóság, PVD eljárás, felületkezelés.

\section{Bevezetés}

A szerszámacélokat a velük szemben támasztott követelmény, mint a nagy keménység, szívósság, kopásállóság és egyéb meghatározó mechanikai tulajdonságaik, alapján lehet minőség szerint besorolni.

Mivel az acélok fejlesztése a korlátait feszegeti, ezért a dolgozófelület keménységének és kopásállóságának a növelése lett a cél.

A felület keménysége és kopásállósága hagyományos és modern eljárásokkal is növelhető. Különböző termokémiai eljárásokkal (nitridálás, cementálás, boridálás stb.) már régóta sikeresen növelik az acélok keménységét, kopásállóságát. Újabb fejlesztések a PVD- és CVD-technológiával történő felületkezelések, amikor a szerszám felületén vékony, kemény réteget építenek fel [1, 2]. A XIX. század végén a forgácsolási technológia fejlesztése miatt a szerszámokat nagy sebességű forgácsolási munkákhoz alkalmazták, emiatt új szerszámokra volt szükség, és kifejlesztették a gyorsacélokat. Az első gyorsacéltípus 1910-ben került nyilvántartásba, T1 jellel, melyet a Crucible Steel Co. szabadalmaztatott. Az akkori volfrámhiány miatt molibdént kezdtek alkalmazni, mellyel újabb acéltípusokat fejlesztettek ki [3, 4]. 


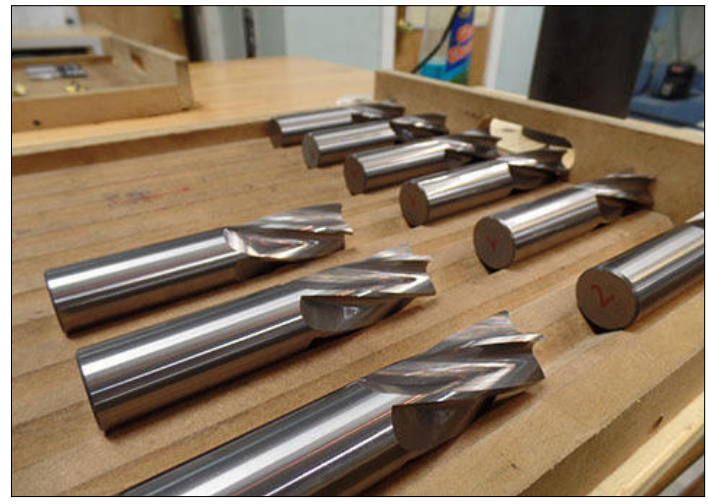

1. ábra. Bevonatolt szerszámok

A 60-as években az acélok fejlesztése, a növelt szilárdságú acélok megjelenése a piacon a szerszámanyagokkal szemben is magasabb elvárásokat támasztott. A forgácsolási követelmények teljesítésére ezért a szerszámacélok felületkezelésével válaszoltak a szerszámgyártók.

A hagyományos eljárásokat is jelentősen fejlesztették, de emellett még a bevonatolási technológiák (PVD, CVD stb.) is terjedni kezdtek. A bevonatok, a hagyományos felületkezelési eljárásokkal szemben a keménységet és kopásállóságot akár három-tízszeresére tudták növelni. Az 1. ábra PVD-bevonatolt szerszámokat mutat be.

\section{Hagyományos felületkezelési eljárások}

A felületi hőkezelések (kérgesítő eljárások) célja kemény, kopásálló felületi kéreg létrehozása az alapanyag magrésze szívósságának megtartása mellett. A hevítésnek igen gyorsan, néhány $100^{\circ} \mathrm{C} / \mathrm{s}$ sebességgel végbe kell mennie, hogy a már nemesített anyag szövetszerkezete ne módosuljon. A hagyományos felületkezelések közül a gyakorlatban a legismertebbek a felületi edzés, a betétedzés és a nitridálás [5].

\subsection{Felületi edzés}

A felületi edzés a darab hevítéséből és gyors hütéA felületi edzés a darab hevítéséből és gyors hütéséből áll. A kiinduló alapszövet a nemesítéssel létrehozott szferoidit. Ez biztosítja a mag szívósságát és szilárdságát. A kéreg keménységét és kopásállóságát pedig a martenzit adja. Martenzites átalakulásról akkor beszélünk, ha a lehűtés olyan gyors, hogy diffúzióra nincs idő, az átalakulás nem egyensúlyi. A folyamatot két ellentétes hatás befolyásolja: a túlhűtés miatt a gamma-alfa átalakulási kényszer nő, viszont a túlhűtés következtében olyan alacsony hőmérsékletet hozunk létre, amin a diffúziós átalakulás sebessége lecsökken. E két hatás eredményeképpen a gammavas rácsátbillenéssel, az atomok egyidejű együttes mozgásával változik FKK-rácsból TKK-ráccsá. Mivel azonban a TKK-rácsnak sokkal kisebb a karbonoldó képesége, az alfarácsnak egy túltelített és tetragonálissá torzult formája jön létre. Ezt hívjuk martenzitnek, ez adja a kéreg keménységét. A felületi edzés lényege tehát, hogy a hőkezelési ciklust olyan sebességgel végzik, hogy a kéregben elég idő legyen az allotrópátalakulásra és az abból való hütésre, de a munkadarab belsejének már ne legyen elég ideje az átedződésre. A felület és a mag közötti hőmérséklet-különbségekből jelentős feszültségek keletkeznek. Ezen feszültségeket $150-200^{\circ} \mathrm{C}$ közötti feszültségmentesítéssel lehet csökkenteni. A felületi edzés több módon végezhető, az eljárásokat a hevítéshez használt energiaforrások szerint csoportosíthatjuk. Eszerint létezik pl.:

- lángedzés,

- indukciós edzés,

- elektronsugaras edzés,

- lézersugaras edzés.

Lángedzéssel nagyobb kéregvastagság hozható létre (1,5-12 mm). Indukciós edzésnél a váltakozó áram frekvenciájának változtatásával szabályozható a kezelt réteg vastagsága [6, 7]. Minél nagyobb a frekvencia, annál vékonyabb réteg hevül fel, a beedzett réteg néhány tized mm-től max. 10 $\mathrm{mm}$-ig terjedhet). Indukciós hevítéssel lényegesen gyorsabban érhető el az előírt hőmérséklet a hagyományos módszerekhez képest. Más edzési eljárással szemben a legalapvetőbb különbség, hogy a hő magában a munkadarabban keletkezik az indukált örvényáramok révén [8, 9].

\subsection{Betétedzés}

A betétedzés sajátossága, hogy a kezelni kívánt alkatrész felületét karbonnal dúsítják, majd edzik. A munkadarab szívósságát az acél alacsony karbontartalma biztosítja, a kéreg keménységét pedig a diffúzióval növelt karbontartalmú réteg edzett, martenzites szövetszerkezete. A megfelelő szívósság érdekében tehát alacsony karbontartalmú, (C < 0,25\%) nem edzhető minőségeket használnak. A mag szilárdságát ötvözéssel javítják. A karbonfelületbe diffundálásának (cementálásnak) köszönhetően viszont a kéreg karbontartalma akár a szerszámacélokéval megegyező mértékűre növelhető, $(0,6 \%<C<1 \%)$ így edzhetővé válik. Ha a cementálást követően edzik a darabot, a mag az alacsony C-tartalom miatt nem tud beedződni, tehát szívós tulajdonságát megőrzi. 
A kéreg pedig a karbon- és egyéb ötvözőanyagoktól, valamint az edzéstől függően kemény, kopásálló lesz. A cementálás hőmérséklete $850-950^{\circ} \mathrm{C}$. A betétedzéssel elért kéregvastagság néhány tized mm-től kb. 2 mm-ig terjed. A betétedzés után megeresztő hőkezelésnek vetik alá a darabot, ami 180-200 ${ }^{\circ} \mathrm{C}$-on zajlik. Ezzel az eljárással 55-65 HRC felületi keménység érhető el.

\subsection{Nitridálás}

A nitridálás az acélok olyan termokémiai kezelése, amelynek célja a felület nitrogénnel történő, diffúzió általi dúsítása. A munkadarab magjának szilárdsága és szívóssága a nemesített (szferoidites) szövetszerkezetnek köszönhető. A kéreg keménységét a nitrogénnek a nitridképző ötvözőelemekkel (Al, Mo, Ti, V) létrehozott nitridvegyületei biztosítják. A nitridálhatóság tehát az ötvözőelemektől függ. Mivel nitridálással csak a felületi réteget kezeljük, a mag megfelelő szívósságát és szilárdságát még a nitridálás előtt nemesítéssel biztosítják. A nitridálást nitrogénleadó közegben (leggyakrabban ammónia) végzik. A nitrogén a felületbe diffundálva, az ötvözőkkel nitrideket képez. A nitridálási hőmérséklet kisebb, mint az acél nemesítésekor alkalmazott megeresztési hőmérséklet. Nitridálással nagyobb felületi keménység érhető el, mint betétedzéssel, (1000-1200 HV) viszont maximum 0,1-0,2 mm-es kéregvastagság érhető el $[10,11]$.

\section{Modern felületkezelési eljárások}

A gőzfázisból történő bevonatképzési módszereket alapvetően két fő csoportba oszthatjuk: fizikai gőzfázisú bevonás (Physical Vapour Deposition, vagyis PVD) és kémiai gőzfázisú bevonás (Chemical Vapour Deposition, vagyis CVD). Ezen eljárásokat soroljuk a modern bevonatolási eljárások közé [11-13].

\subsection{PVD- vagy fizikai gőzfázisú bevonatolás}

A fizikai gőzfázisú rétegleválasztás során a bevA fizikai gőzfázisú rétegleválasztás során a bevonatot képező anyagot atomos, molekuláris vagy ionos formában viszik fel a bevonandó alkatrész felületére. A bevonatot szilárd, folyékony vagy gáznemű forrásból viszik fel. A PVD-eljárások viszonylag alacsony hőmérsékleten $\left(50^{\circ} \mathrm{C} \ldots 550^{\circ} \mathrm{C}\right)$ mennek végbe. Ez azt jelenti, hogy az eljárás nem módosítja a réteg alatti hordozóanyag szövetszerkezetét, ami több szempontból is kedvező [13, 14]. Egyrészt nincs allotróp átalakulás, tehát az ebből adódó méretváltozást is elkerüljük, más-

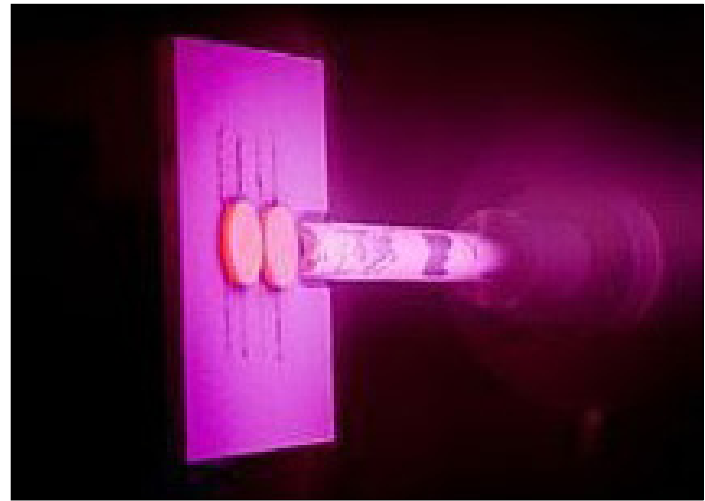

2. ábra. PVD-bevonatolás

részt tudjuk, hogy módosult szövetszerkezetben máshogy oldódnak az ötvözők és a diffúzióval bevitt bevonandó anyag. Továbbá alkalmazható edzett és megeresztett gyorsacél szerszámokon is a kilágyulás veszélye nélkül. Lehúléskor pedig több vetemedéssel és több maradó feszültséggel lehetne számolni, ami a bevonat stabilitása miatt sem előnyös és a tervezést is nehezíti.

Az elérhető keménység a felületen létrehozott réteg kémiai összetételétől függ. A 2 . ábrán a bevonatolás látható.

\subsection{CVD- vagy kémiai gőzfázisú bevonatolás}

A kémiai gőzfázisú bevonás hasonlóan sokoldalúan alkalmazható eljárás, mellyel szinte bármilyen fém és nemfémes (pl. karbon, szilícium) anyagú bevonat felvitelére lehetőség nyílik. Tehát vegyületek (nitridek, karbidok, oxidok) és sok más anyag is felvihető ezzel az eljárással. Az eljárás során két vagy több megfelelő összetételü, gázállapotú vegyületet egy reaktorkemencébe vezetnek, és termikusan, (hagyományos CVD-) vagy más módon (pl. plazmával vagy lézerrel előidézett CVD) a bevonandó tárgy felületének közelében reakcióba visznek, aminek hatására termokémiai bomlás és további reakciók játszódnak le. A keletkező reakciótermék az alkatrész felületére lecsapódva szilárd bevonatot képez, azonban itt gázfázisú melléktermék is keletkezik. Az eljárás a PVD-hez hasonlóan vákuumban történik, a hőmérséklet viszont $600-1100^{\circ} \mathrm{C}$ közötti tartományban van. A magas hőmérséklet által elősegített diffúziónak köszönhetően a CVD-eljárással egyenletes vastagságú, kis porozitású, megfelelő tapadású bevonat hozható létre, akár bonyolult alakú munkadarabon is. Amíg azonban a szinterelt karbid hordozóanyag torzulás nélkül bírja a magas hőmérsékletet, addig szerszámacélok esetében megkerülhetetlen az utólagos hőkezelés (edzés 
és megeresztés), és ezzel együtt is számolni kell bizonyos mértékű deformációval. Ezért a napjainkban zajló CVD-eljárásokhoz füződő kutatások is az alacsony hőmérsékletű eljárások kifejlesztését célozzák meg.

\section{4. Összefoglalás}

A nagy kopásnak kitett alkatrészek és szerszámok elvárt felületi keménysége és kopásállósága az ismertetett eljárásokkal, illetve ezek kombinációival valósíthatók meg. Mind a hagyományos, mind a modern felületi eljárásokat folyamatosan fejlesztik, mely tovább növelheti a kezelt munkadarabok élettartamát és hatékony alkalmazását.

\section{Köszönetnyilvánítás}

A szerzők köszönetet mondanak a támogatásért a magyar államnak és a Nemzeti Kutatási, Fejlesztési és Innovációs Hivatalnak a támogatásért a TÉT-201900093 számú projekt megvalósításában.

\section{Szakirodalmi hivatkozások}

[1] Sandvik Coromant: Forgácsolószerszám-anyagok (letöltés: 2019. október 24.)

https://www.sandvik.coromant.com/hu-hu/ knowledge/materials/pages/cutting-tool-materials.aspx

[2] Böhler S600. High Speed Steel, 2007. (Letöltés: 2020. 03. 03.)

https://www.boehler.hu/app/uploads/sites/92/ productdownloads/S600DE.pdf

[3] Böhler S600. Termékleírás. (Letöltés: 2020. 03. 03.) https://www.boehler.hu/hu/products/s600/

[4] Böhler S600, High Performance Materials for High Performance Tools. 2018. (Letöltés: 2020. 03 03.) https://www.bohler-edelstahl.com/app/uploads/ sites/92/2019/09/S000En.pdf

[5] Sebestyén A., Nagyné Halász E., Bagyinszky Gy., Bitay E.: Felületmódosítási eljárások hatása acélok kopásállóságára. XII. FMTÜ, EME, Kolozsvár, 2007. 161-169. https://doi.org/10.36243/fmtu-2007.4
[6] Bagyinszky Gy., Bitay E.: Kopásálló felületkezelt rétegek minősítése./Characterization of surface treated, wear resistant layers. XIV. FMTÜ, Kolozsvár, 2009. 13-16.

https://doi.org/10.36243/fmtu-2009.08

[7] Bitay E.: Bevonatolt gyorsacélok kopásállósága/ Coated HS steels wear resistance. XVIII. FMTÜ, EME, Kolozsvár, 2013. 73-76.

https://doi.org/10.36243/fmtu-2013.10

[8] Kovács T. A., Bitay E.: The Hardness Control in the Coated Surface Layer. Materials Science Forum, (0255-5476 1662-9752): Volume 729, (2012), pp. 415-418.

https://doi.org/10.4028/www.scientific.net/ MSF.729.415

[9] Kovács T. A.: Nano-mechanical and surface morphological properties of TiN coating produced by PVD in tool steel. Materials Science Forum, 659. (2010), 191-196.

https://doi.org/10.4028/www.scientific.net/ MSF.659.191

[10] Kovács T., Dévényi L.: Investigation of wear process by a gradient method. Materials Science Forum, 473-474. (2005), 213-218.

https://doi.org/10.4028/www.scientific.net/ MSF.473-474.213

[11] Totten G. E.: Steel Heat Treatment: Metallurgy and Technologies. CRC Press, Taylor and Francis Group, 2006 Oregon USA .

[12] Kovács-Coskun T., Bitay E.: The hardness control in the coated surface layer. Materials Science Forum, 729. (2013) 415-418.

https://doi.org/10.4028/www.scientific.net/ MSF.729.415

[13] Bagyinszki Gyula, Bitay Enikő: Felületkezelés. Műszaki Tudományos Füzetek 5., EME, Kolozsvár, 2009.

https://doi.org/10.36242/mtf-05

[14] Bitay E., Kovács T.: The effect of the laser surface treatments on the wear resistance. Materials Science Forum, 649. (2010) 107-112.

https://doi.org/10.4028/www.scientific.net/ MSF.649.107 